\title{
Development and Validation of RP-HPLC Method for Simultaneous Determination of Diclofenac Sodium and Eperisone Hydrochloride in Pharmaceutical Dosage Form
}

\section{Divya $\mathbf{A}^{1}$, Vishwanadham $\mathbf{Y}^{2^{*}}$ and Mounika}

${ }^{1}$ Department of Pharmaceutical Analysis and QA, Vishnu Institute of Pharmaceutical Education and Research, Telangana 502313, India

${ }^{2}$ Department of Pharmaceutical Chemistry, Vishnu Institute of Pharmaceutical Education and Research, Telangana 502313, India

*Corresponding author: Vishwanadham Y, Department of Pharmaceutical Chemistry, Vishnu Institute of Pharmaceutical Education and Research, Narsapur, Medak-502313, Telangana, India, Tel: 040-64634235; E-mail: Vishwanadham.y@gmail.com

Received date: May 17, 2017; Accepted date: June 21, 2017; Published date: June 26, 2017

Copyright: (C) 2017 Divya A, et al. This is an open-access article distributed under the terms of the Creative Commons Attribution License, which permits unrestricted use, distribution, and reproduction in any medium, provided the original author and source are credited.

\section{Abstract}

The RP-HPLC (Reversed-Phase High-Performance Liquid Chromatography) method was developed for the simultaneous determination of Eperisone Hydrochloride and Diclofenac Sodium in capsule dosage form. After that optimization good chromatographic separation was achieved by Isocratic mode with a mixture of Acetonitrile: Phosphate buffer $\mathrm{pH}-5.8$ in the ratio $55: 45 \mathrm{v} / \mathrm{v}$ as the mobile phase and detection wavelength of $225 \mathrm{~nm}$. The drud retention times for Eperisone Hydrochloride and Diclofenac Sodium found to be $3.143 \mathrm{~min}$ and $4.753 \mathrm{~min}$ respectively. The linearity, this method was found in the concentration range of $90-210 \mu \mathrm{g} / \mathrm{ml}$ for Eperisone Hydrochloride and 60-140 $\mathrm{\mu g} / \mathrm{ml}$ for Diclofenac Sodium. The LOD and LOQ for Eperisone Hydrochloride were found to be 1.55 and $4.71 \mu \mathrm{g} / \mathrm{ml}$ respectively. The LOD and LOQ for Diclofenac Sodium were found to be 2.08 and 6.31 $\mu \mathrm{g} / \mathrm{ml}$ respectively. This method was found to be good as the percentage recovery for Eperisone Hydrochloride and Diclofenac Sodium were found to be 100.86 and 99.81 respectively, which indicates that the proposed method is highly accurate. The specificity of the method shows good correlation between retention times of standard with the drug so, the sample without interference from excipients of capsule dosage form.
\end{abstract}

Keywords: UV spectrophotometer; Eperisone $\mathrm{HCl}$; Diclofenac sodium; High Performance Liquid Chromatography (HPLC)

\section{Introduction}

Chromatography is the technique in which the components in a mixture of sample separated by passing through stationary phase with aid of mobile phase. The components which have more affinity with mobile phase elute faster than others. HPLC is the fastest growing analytical technique for analysis of drugs. Its simplicity, high specificity and wide range of sensitivity make it ideal for the analysis of many drugs in various dosage forms and biological fluids. The HPLC is the vital tool in the field of analysis of various pharmaceutical dosage forms, since this method is specific, robust, linear, precise and accurate and the limit of detection is low. The method development is an integral part of the method validation. Establishing documented evidence, provides that a specific activity will consistently produce a desired result or product meeting its predetermined specifications and quality characteristics of the samples [1-14].

The validation parameters are Specificity, linearity, Accuracy, LOD, LOQ, Precision, Range, Robustness, System suitability (Figures 1 and 2).

\section{Drug profile}

IUPAC name: 1-Propanone,1-(4-ethylphenyl)-2-methyl-3-(1piperidinyl)-, hydrochloride.

Molecular formula: $\mathrm{C}_{17} \mathrm{H}_{26} \mathrm{NOCl}$

Molecular weight: 295.89
Category: Muscle relaxant.

Description: White crystalline powder.

Solubility: Freely soluble in water, methanol, and acetic acid.

Storage: Eperisone hydrochloride should be stored at temperatures not exceeding $30^{\circ} \mathrm{C}$, and should be protected from moisture after opening package.<smiles>CCc1ccc(C(=O)C(C)CN2CCCCC2)cc1</smiles>

Figure 1: Eperisone hydrochloride.

IUPAC name: 2-[(2-aminoethoxy)methyl]-4-(2-chlorophenyl)-3ethoxycarbonyl-5-methoxycarbonyl-6-methyl-1, 4-dihydropyridine benzenesulfonate.

Molecular formula: $\mathrm{C}_{20} \mathrm{H}_{25} \mathrm{ClN}_{2} \mathrm{O}_{5} \cdot \mathrm{C}_{6} \mathrm{H}_{6} \mathrm{O}_{3} \mathrm{~S}$

Molecular weight: 567.05

Category: Anti-hypertensive (calcium channel blocker).

Description: White powder. 
Citation: Divya A, Vishwanadham Y, Mounika (2017) Development and Validation of RP-HPLC Method for Simultaneous Determination of Diclofenac Sodium and Eperisone Hydrochloride in Pharmaceutical Dosage Form. Pharm Anal Acta 8: 552. doi: $10.4172 / 2153-2435.1000552$

Page 2 of 6

Solubility: Slightly soluble in distilled water and sparingly soluble in ethanol.

Storage: Diclofenac Sodium should be kept in a tightly closed container, protected from light.

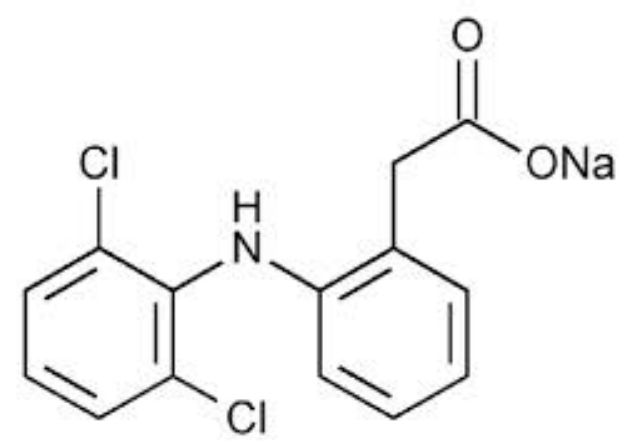

Figure 2: Diclofenac sodium.

\section{Material and Methods}

\section{Instruments}

UV-Visible Spectrophotometer, HPLC, Ultra sonicator, $\mathrm{pH}$ meter, Electronic balance, Syringe, HPLC Column

\section{Chemicals}

Sodium dihydrogen ortho phosphate, acetonitrile, water, ethanol, Ammonium acetate, sodium hydroxide, hydrochloric acid, disodium hydrogenphophate.

Preparation of $0.05 \mathrm{M}$ potassium dihydrogen phosphate buffer $\mathrm{pH}$ 5.8: $1.6 \mathrm{~g}$ of potassium dihydrogen phosphate and $0.3 \mathrm{~g}$ dipotassium hydrogen Phosphate was weighed dissolved in $100 \mathrm{ml}$ of water and make up to $550 \mathrm{ml}$ with water. To the above solution $450 \mathrm{ml}$ of Acetonitrile was added. The buffer was filtered through $0.45 \mu \mathrm{m}$ membrane filters to remove all fine particles and gases.

\section{Results and Discussion}

\section{Preparation of standard solution}

About $150 \mathrm{mg}$ of EP and $100 \mathrm{mg}$ of DF were weighed into a $100 \mathrm{ml}$ volumetric flask, to this $25 \mathrm{ml}$ of liquid mobile phase was added.

\section{Dilutions}

Necessary dilutions are made from the standard stock solutions to get the concentration range $10 \mu \mathrm{g} / \mathrm{ml}$ of EP and DF (Figure 3 ).

\section{Preparation of standard stock solution}

Weighed accurately $1.5 \mathrm{mg}$ of EP and $1 \mathrm{mg}$ of DF in $50 \mathrm{ml}$ of volumetric flask and make up the volume using mobile phase. From above stock solution $1 \mathrm{ml}$ of EP and DF were diluted to $10 \mathrm{ml}$ with mobile phase. From the above solution $1.5 \mathrm{ml}$ of EP and $1 \mathrm{ml}$ of DF is taken into vial. This method was finalized for the simultaneous determination of EP and DF (Figure 4).
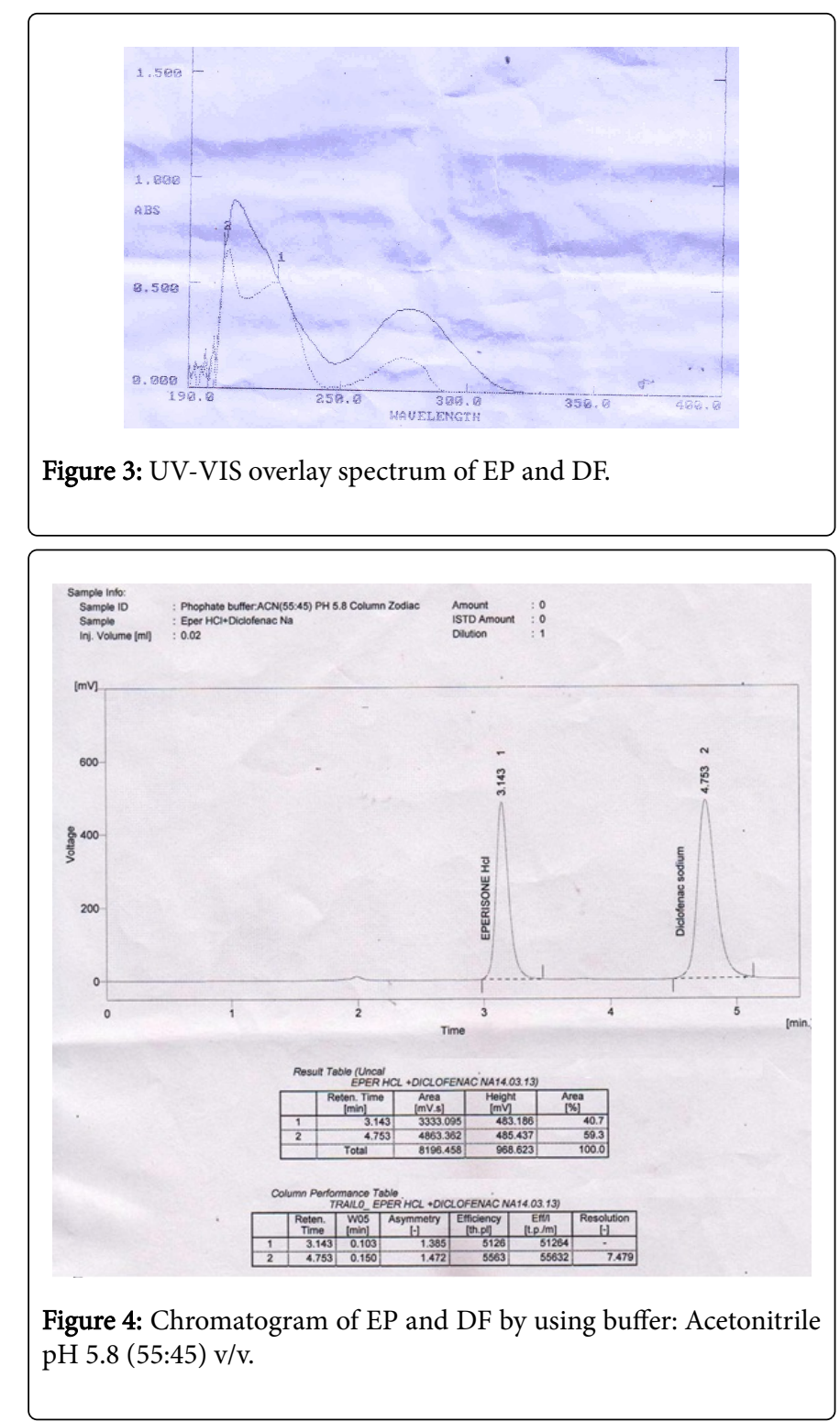

The EP peak was observed at 3.143 min with peak area 3333.095 , theoretical plates 5126 and tailing factor 1.385. The DF peak was observed at 4.753 min with peak area 4863.362 , theoretical plates 5563 and tailing factor 1.472. The Retention time of EP and DF are satisfactory and this trial is less solvent consuming and less time consuming with good resolution.

\section{Precision}

Precision was determined by using sample solutions of concentration EP $(80 \mu \mathrm{g} / \mathrm{ml})$ and DF $(8 \mu \mathrm{g} / \mathrm{ml})$ for six times are prepared separately. The chromatograms were recorded and the results were summarized \% RSD of retention time and peak areas obtained for EP were 0.76 and 1.93 respectively and for DF were 1.11 and 1.76 respectively (Table 1).

$\%$ RSD of 6 determinations of EP and DF for system precision found within the acceptance criteria of less than $2.0 \%$. 
Citation: Divya A, Vishwanadham Y, Mounika (2017) Development and Validation of RP-HPLC Method for Simultaneous Determination of Diclofenac Sodium and Eperisone Hydrochloride in Pharmaceutical Dosage Form. Pharm Anal Acta 8: 552. doi: $10.4172 / 2153-2435.1000552$

Page 3 of 6

\begin{tabular}{|c|c|c|c|c|}
\hline \multirow{2}{*}{ Injection } & \multicolumn{2}{|c|}{ EP } & \multicolumn{2}{c|}{ DF } \\
\cline { 2 - 5 } & Rt & Area & Rt & Area \\
\hline 1 & 3.307 & 5588.309 & 5.273 & 6877.737 \\
\hline 2 & 3.297 & 5580.255 & 5.24 & 6868.255 \\
\hline 3 & 3.29 & 5561.278 & 5.227 & 6981.498 \\
\hline 4 & 3.277 & 5442.266 & 5.2 & 6748.14 \\
\hline 5 & 3.27 & 5649.455 & 5.213 & 6634.942 \\
\hline 6 & 3.237 & 5362.187 & 5.103 & 6796.623 \\
\hline Average & 3.2797 & 5530.63 & 5.209 & 6817.866 \\
\hline SD & 0.0248 & 106.798 & 0.058 & 119.727 \\
\hline \%RSD & 0.76 & 1.93 & 1.11 & 1.76 \\
\hline
\end{tabular}

\begin{tabular}{|c|c|c|}
\hline S. No. & Concentration $(\boldsymbol{\mu g} / \mathrm{ml})$ & Area \\
\hline 1 & 60 & 4048.701 \\
\hline 2 & 80 & 5632.602 \\
\hline 3 & 100 & 7256.338 \\
\hline 4 & 120 & 8817.203 \\
\hline 5 & 140 & 10093.89 \\
\hline
\end{tabular}

Table 3: Linearity data of DF.

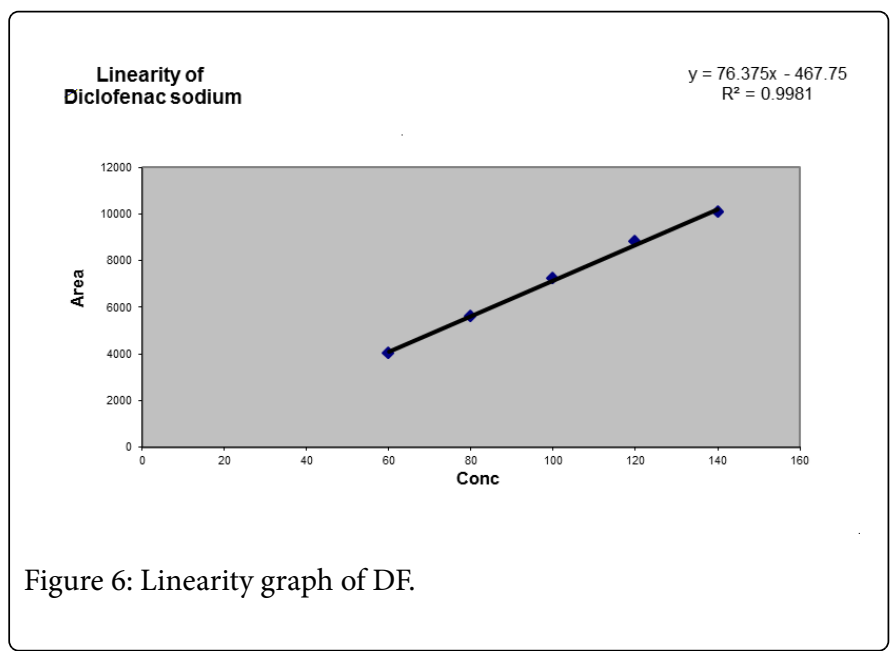

Correlation coefficient of linear curve obtained and the graph between concentration vs. Area for standard preparations of EP and $\mathrm{DF}$ is 0.997 and 0.998 respectively.

\section{Limit of Detection (LOD) and Limit of Quantitation (LOQ)}

The LOD for this method was determined to be $0.09 \mu \mathrm{g} / \mathrm{ml}$ for EP and $0.07 \mu \mathrm{g} / \mathrm{ml}$ for DF respectively. The LOQ for this method was determined to be $0.27 \mu \mathrm{g} / \mathrm{ml}$ for EP and $0.23 \mu \mathrm{g} / \mathrm{ml}$ for DF respectively.

\section{Specificity}

Preparation of standard stock solution: A standard stock solution of $\mathrm{EP}$ and $\mathrm{DF}(\mathrm{mg} / \mathrm{ml})$ was prepared and dissolving $150 \mathrm{mg}$ of EP and $100 \mathrm{mg}$ of DF in $100 \mathrm{ml}$ of mobile phase. The above solution is filtered by using 0.45 -micro filter and sonicated for $5 \mathrm{~min}$. Further dilution of $150 \mu \mathrm{g} / \mathrm{ml}$ of EP and $100 \mu \mathrm{g} / \mathrm{ml}$.

The standard solution was injected thrice and the chromatogram was recorded and the retention times for EP and DF were found to be 2.373 and 5.163 min respectively.

Figure 5: Linearity of EP. 
Citation: Divya A, Vishwanadham Y, Mounika (2017) Development and Validation of RP-HPLC Method for Simultaneous Determination of Diclofenac Sodium and Eperisone Hydrochloride in Pharmaceutical Dosage Form. Pharm Anal Acta 8: 552. doi: $10.4172 / 2153-2435.1000552$

\begin{tabular}{|c|c|c|c|}
\hline \multicolumn{4}{|c|}{ Sample Info: } \\
\hline Sample ID & : Specificity & Amount & $: 0$ \\
\hline Sample & : Eperisone $\mathrm{HCl}(150 \mathrm{mcg})+$ Diclofenac sodium $(100 \mathrm{mcg})$ & ISTD Amount & $: 0$ \\
\hline Inj. Volume [ml] & $: 0.02$ & Dilution & $: 1$ \\
\hline
\end{tabular}

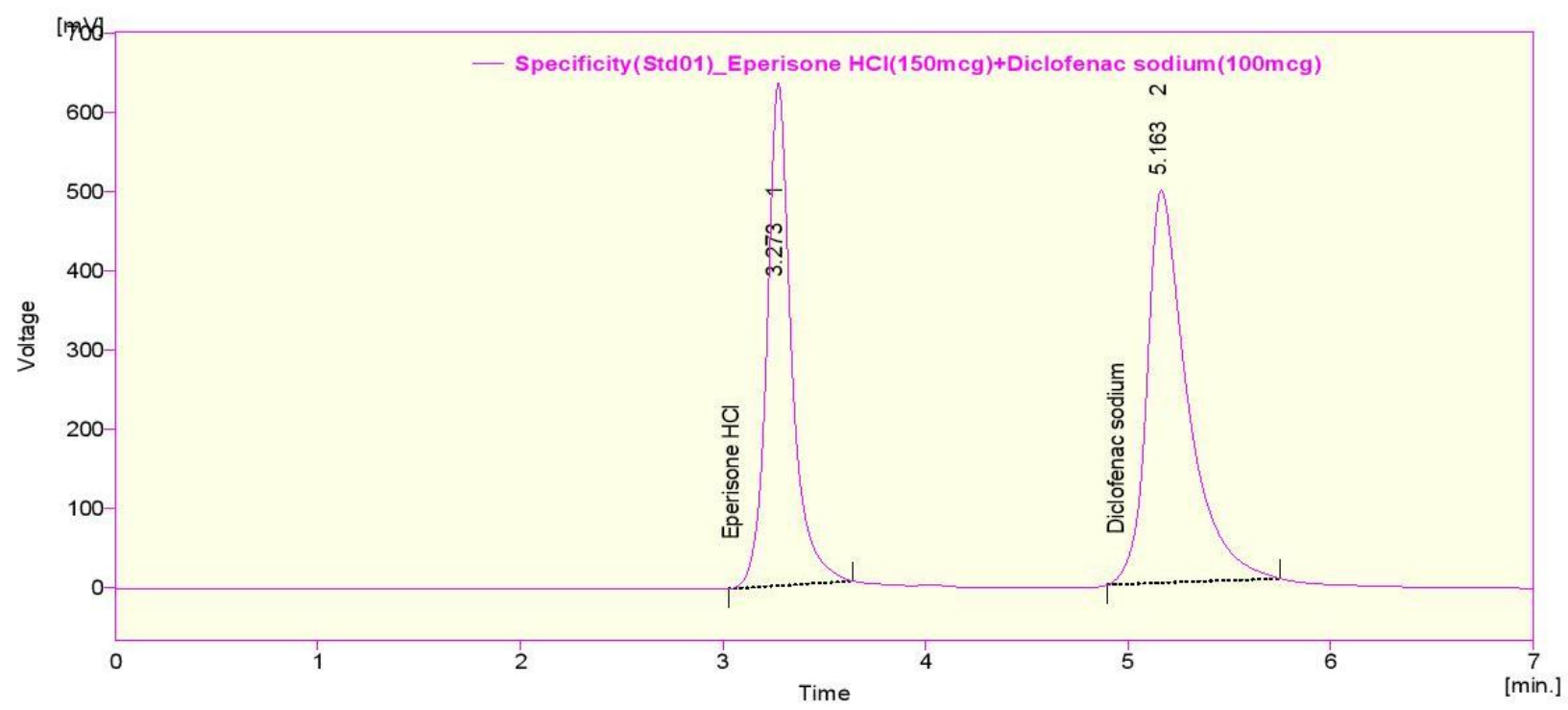

Result Table (Uncal - Specificity(Std01)_Eperisone $\mathrm{HCl}(150 \mathrm{mcg})+$ Diclofenac sodium $(100 \mathrm{mcg})$ )

\begin{tabular}{|c|c|c|c|c|}
\hline & $\begin{array}{l}\text { Reten. Time } \\
{[\text { [min] }}\end{array}$ & $\begin{array}{c}\text { Area } \\
{[\mathrm{mV} . \mathrm{s}]}\end{array}$ & $\begin{array}{l}\text { Height } \\
{[\mathrm{mV}]}\end{array}$ & $\begin{array}{c}\text { Area } \\
{[\%]}\end{array}$ \\
\hline 1 & 3.273 & 5324.780 & 634.885 & 43.6 \\
\hline \multirow[t]{2}{*}{2} & 5.163 & 6881.306 & 495.888 & 56.4 \\
\hline & Total & 12206.086 & 1130.774 & 100.0 \\
\hline
\end{tabular}

Column Performance Table (From 50\% - Specificity(Std01)_Eperisone $\mathrm{HCl}(150 \mathrm{mcg})+$ Diclofenac sodium $(100 \mathrm{mcg}))$

\begin{tabular}{|c|c|c|r|r|r|c|}
\hline & $\begin{array}{c}\text { Reten. } \\
\text { Time }\end{array}$ & $\begin{array}{c}\text { W05 } \\
{[\mathrm{min}]}\end{array}$ & $\begin{array}{c}\text { Asymmetry } \\
{[-]}\end{array}$ & $\begin{array}{c}\text { Efficiency } \\
{[\text { th.pl] }}\end{array}$ & $\begin{array}{c}\text { Eff/ } \\
{[\text { t.p. } / \mathrm{m}]}\end{array}$ & $\begin{array}{c}\text { Resolution } \\
{[-]}\end{array}$ \\
\hline 1 & 3.273 & 0.120 & 1.314 & 4122 & 41222 & - \\
\hline 2 & 5.163 & 0.200 & 1.868 & 3692 & 36924 & 6.951 \\
\hline
\end{tabular}

Figure 7: Chromatogram of EP and DF standards.

\section{Accuracy}

To the formulation (pre analysed sample), the reference standards of the drugs were added at the level of $80 \%, 100 \%, 120 \%$, the method was determined by recovery studies.

Tablet sample preparation: $150 \mathrm{mg}$ of $\mathrm{EP}$ and $100 \mathrm{mg}$ of $\mathrm{DF}$ combined tablets was taken into a mortar and crushed to fine powder and mixed. Tablet stock solutions of EP and DF (microgram $/ \mathrm{ml}$ ) were prepared by dissolving equivalent weight $150 \mathrm{mg}$ of EP and $100 \mathrm{mg}$ of $\mathrm{DF}$ in $50 \mathrm{ml}$ of mobile phase. The above solution is filtered by using 0.45 -micron syringe filter and sonicated for $5 \mathrm{~min}$. Further dilution of $150 \mu \mathrm{g} / \mathrm{ml}$ of EP and $100 \mu \mathrm{g} / \mathrm{ml}$ was made.

The tablet sample solution was injected thrice and the chromatogram was recorded and the retention times for EP and DF were 3.273 and $5.167 \mathrm{~min}$ respectively (Table 4 ).

\begin{tabular}{|c|c|c|c|c|c|}
\hline \multirow{2}{*}{ Chromatographic changes } & \multicolumn{2}{c|}{ Retention time(min) } & \multicolumn{2}{c|}{ Tailing factor } \\
\cline { 2 - 6 } & EP & DF & EP & DF \\
\hline \multirow{2}{*}{ Flow rate (ml/min) } & 0.8 & 4.1 & 6.253 & 1.256 & 1.852 \\
\cline { 2 - 6 } & 2.1 & 2.77 & 4.28 & 1.429 & 2.057 \\
\hline \multirow{2}{*}{ Wavelength (nm) } & 219 & 2.27 & 5.137 & 1.324 & 1.963 \\
\cline { 2 - 6 } & 223 & 3.25 & 5.083 & 1.294 & 1.968 \\
\hline
\end{tabular}

Table 4: Retention time and Tailing factor of EP and DF. 
Citation: Divya A, Vishwanadham Y, Mounika (2017) Development and Validation of RP-HPLC Method for Simultaneous Determination of Diclofenac Sodium and Eperisone Hydrochloride in Pharmaceutical Dosage Form. Pharm Anal Acta 8: 552. doi: $10.4172 / 2153-2435.1000552$

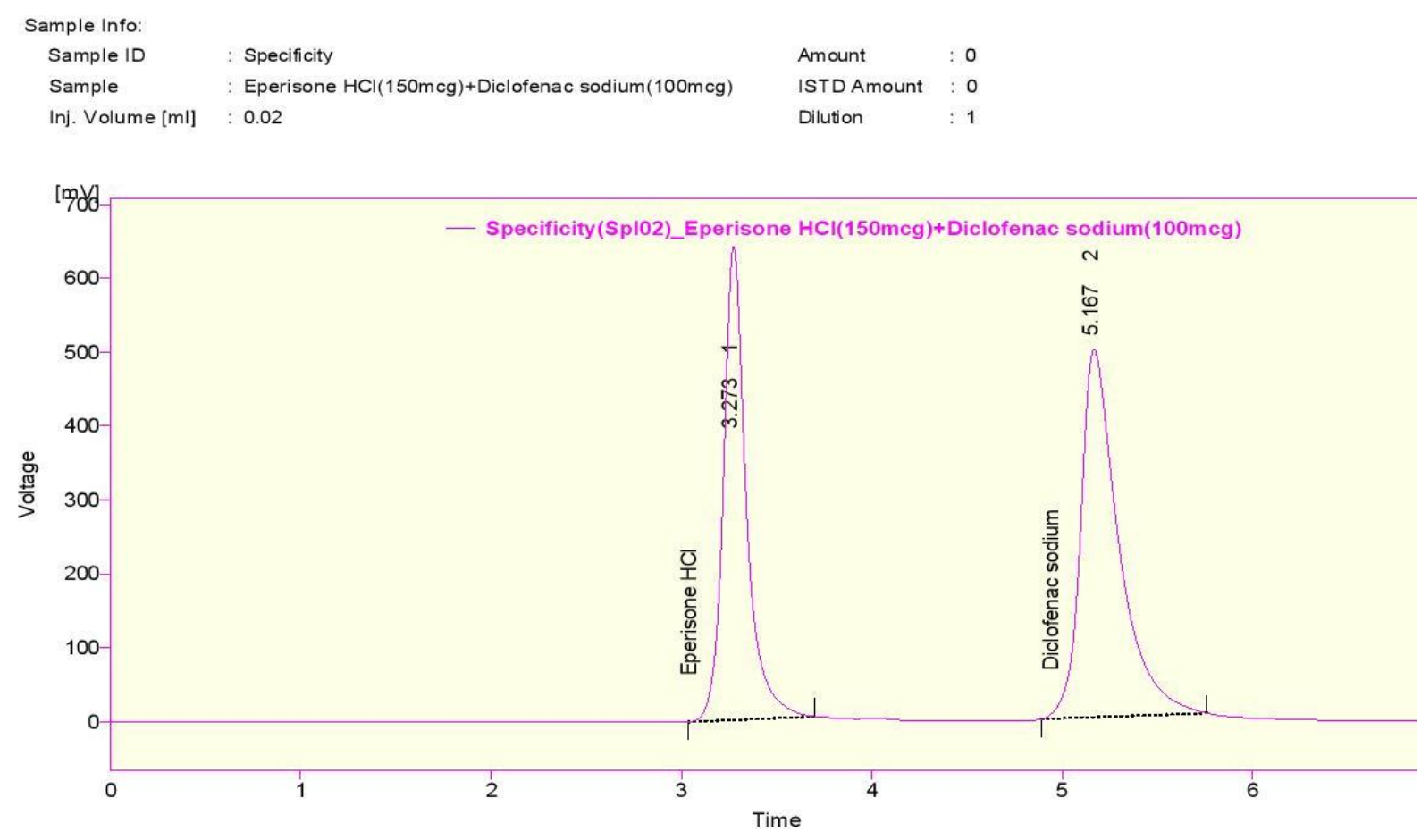

Result Table (Uncal - Specificity(SplO2)_Eperisone $\mathrm{HCl}(150 \mathrm{mcg})+$ Diclofenac sodium $(100 \mathrm{mcg})$ )

\begin{tabular}{|c|c|c|c|r|}
\hline & $\begin{array}{c}\text { Reten. Time } \\
{[\mathrm{min}]}\end{array}$ & $\begin{array}{c}\text { Area } \\
{[\mathrm{mV} . \mathrm{s}]}\end{array}$ & $\begin{array}{c}\text { Height } \\
{[\mathrm{mV}]}\end{array}$ & \multicolumn{1}{c|}{$\begin{array}{c}\text { Area } \\
{[\%]}\end{array}$} \\
\hline 1 & 3.273 & 5374.321 & 641.181 & 43.7 \\
2 & 5.167 & 6911.153 & 497.842 & 56.3 \\
& Total & 12285.474 & 1139.023 & 100.0 \\
\hline
\end{tabular}

Column Performance Table (From 50\% - Specificity(SplO2)_Eperisone $\mathrm{HCl}(150 \mathrm{mcg})+$ Diclofenac sodium $(100 \mathrm{mcg})$ )

\begin{tabular}{|c|c|c|r|r|r|c|}
\hline & $\begin{array}{c}\text { Reten. } \\
\text { Time }\end{array}$ & $\begin{array}{c}\text { W05 } \\
{[\mathrm{min}]}\end{array}$ & $\begin{array}{c}\text { Asymmetry } \\
{[-]}\end{array}$ & $\begin{array}{c}\text { Efficiency } \\
{[\text { th. pl] }}\end{array}$ & $\begin{array}{c}\text { Eff/l } \\
{[\text { [t.p./m] }}\end{array}$ & $\begin{array}{c}\text { Resolution } \\
{[-]}\end{array}$ \\
\hline 1 & 3.273 & 0.120 & 1.424 & 4122 & 41222 & - \\
\hline 2 & 5.167 & 0.200 & 1.962 & 3697 & 36972 & 6.963 \\
\hline
\end{tabular}

Figure 8: Specificity for EP and DF.

The tailing factor was found to be within the limits on small variation of flow rate and wavelength (Figures 6-8).

\section{Conclusion}

The optimum wavelength for the estimation of DF and EP was selected at $225 \mathrm{~nm}$ on the basis of isobestic point. The various trials were performed with using different mobile phases in different ratios, but Phosphate buffer ( $\mathrm{pH}$ 5.8): Acetonitrile (55:45) was selected and find the good peak and resolution. The retention time of EP and DF were found to be 3.143 and $4.753 \mathrm{~min}$ respectively. The retention times for both the drugs were considerably less compared to the retention time obtained for the drugs in the other mobile phase.

Different analytical techniques used such as linearity, precision, accuracy, and specificity, LOD, LOQ were estimated and calibration curve for EP was obtained by plotting peak area versus the concentration over the range of $90-210 \mu \mathrm{g} / \mathrm{ml}$ For EP and $60-140$ $\mu \mathrm{g} / \mathrm{ml}$ for DF. From linearity the correlation coefficient R2 value was found to be 0.997 for EP and 0.998 for DF.

RP-HPLC method was also validated for suitability and method precision. The \% RSD in the peak area of drug was found to be less than $2 \%$. The number of theoretical plates was found to be more than 4000, which indicates efficient performance of the column. The limit of detection of EP and DF were found to be $1.55 \mathrm{ppm}$ and $2.08 \mathrm{ppm}$ and limit of quantitation were $4.71 \mathrm{ppm}$ and $6.31 \mathrm{ppm}$ respectively, indicates the sensitivity of the method. The percentage of recovery of EP and DF were found to be 99.72 and 99.84 respectively shows that the proposed method is highly accurate.

Hence the proposed method is highly accurate, precise and sensitive and it is successfully applied for the quantification methods of API formulations. This content is use full in the commercial formulations 
Citation: Divya A, Vishwanadham Y, Mounika (2017) Development and Validation of RP-HPLC Method for Simultaneous Determination of Diclofenac Sodium and Eperisone Hydrochloride in Pharmaceutical Dosage Form. Pharm Anal Acta 8: 552 . doi: $10.4172 / 2153-2435.1000552$

Page 6 of 6

of EP and DF in Educational institutions and Quality control laboratories.

\section{Acknowledgments}

I am grateful to express my heartful thanks to my parents, VIPER Staff and also thanks for their experience advices and constant encouragement.

\section{References}

1. Haritha G, Vishwanadham Y (2016) Development and validation of RPHPLC method for simultaneous estimation of naproxen and esomeprazole in pharmaceutical dosage form. Asian J Res Chem 9: 366-368.

2. Sandhya M, Vishwanadham Y, Umema (2016) Formulation and evaluation of atorvastatin calcium sustained release tablets. Int J Pharm 6: 124-130.

3. Chatwal RG, Anand KS (2010) High performance liquid chromatography. Instrumental methods of chemical analysis. Himalaya Publishers.

4. Sharma BK (2005) High performance liquid chromatography. Instrumental methods of chemical analysis (24th edn.). Goel Publishers, Meerut, India.
5. Dong WM (2006) HPLC instrumentation and trends. Modern HPLC for practicing scientists, USA pp: 78-110.

6. http://www.comsol.com/stories/waters_corp_hplc_systems/full/

7. http://www.sanderkok.com/techniques/hplc/ eluotropic_series_extended.html

8. Swartz ME, Ira KS (2009) Analytical method development and validation (1st edn.). Marcel Dekker, Inc., NY, USA pp: 17-80.

9. Satinder A, Dong MW (2005) Method development and validation. Pharmaceutical analysis by HPLC (15th edn.). NY, USA pp: 16-70.

10. Snyder RL, Kirkland JJ, Glajch LJ (1997) Getting started. Practical HPLC method development (2nd edn.). NY, USA pp: 30-100.

11. http://www.sigmaaldrich.com/etc/medialib/docs/Aldrich/ General_Information/IDFbasics_pg144.Par.0001.File.tmp/ lDFbasics_pg144.pdf

12. International Conference on Harmonisation (ICH) (1995) Text on validation of analytical procedures, ICH-Q2A. IFPMA, Geneva.

13. International Conference on Harmonisation (ICH) (1996) Validation of analytical procedures: methodology, ICH-Q2B, International Conference on Harmonisation pp: 1-3.

14. ICH Guidelines (2005) Q2 (R1)-validation of analytical procedures: Text and Methodology pp: 1-6. 